\title{
Biological Nitrogen and COD Removal of Nutrient-Rich Wastewater Using Aerobic and Anaerobic Reactors
}

\author{
Florante A. MAGNAYE ${ }^{\mathbf{1 , 2}}$, Pag-asa D. GASPILLO ${ }^{1}$, Joseph L. AURESENIA ${ }^{\mathbf{1}}$ \\ ${ }^{1}$ Chemical Engineering Department, De La Salle University-Manila, Manila, Philippines \\ ${ }^{2}$ Chemical Engineering Department, Technological Institute of the Philippines-Manila, Manila, Philippines \\ E-mail:magnayef@yahoo.com \\ Received September 2, 2009; revised September 30, 2009; accepted October 16, 2009
}

\begin{abstract}
A preliminary study on nitrogen and organic removal efficiency of a lab-scale system using aerobic and anaerobic reactors was performed. A simulated wastewater containing elevated levels of nitrogen was used. This paper aims to compare the efficiency of aerobic and anaerobic reactors in achieving nitrogen and chemical oxygen demand (COD) removal of nutrient-rich wastewater. It also presents the start-up experimentation conducted on simulated wastewater using two different reactors configured as aerobic and anaerobic. Start-up experiments were carried out using a 5-liter acrylic aerobic reactor and a 4-liter flask anaerobic reactor containing activated sludge taken from De La Salle University (DLSU) wastewater treatment plant as a source of inoculum. Simulated wastewater was continuously fed to the two reactors and the time course of biomass growth was monitored by measuring the biomass concentration represented by mixed liquor volatile solids (MLVS). The time course of organic pollutant reduction by measuring the chemical oxygen demand (COD) was conducted until steady state condition was reached. On the other hand, COD and nitrogen tests such as Ammonia nitrogen $\left(\mathrm{NH}_{3}-\mathrm{N}\right)$, Nitrite nitrogen $\left(\mathrm{NO}_{2}{ }^{-} \mathrm{N}\right)$, Nitrate nitrogen $\left(\mathrm{NO}_{3}{ }^{-} \mathrm{N}\right)$ were also performed using 5 batch aerobic reactors containing different concentrations of wastewater and a single batch anaerobic reactor to see the effect of different feed concentrations in the removal of nitrogen. Preliminary results showed that $98 \%$ reduction in COD was obtained in aerobic reactor, as supported by increasing concentration of MLVS, with a hydraulic retention time (HRT) of 5 hours after 11 days while $34 \%$ reduction in COD was obtained in anaerobic reactor with the same HRT after 14 days.
\end{abstract}

Keywords: COD, MLVS, HRT, Aerobic, Anaerobic Reactors

\section{Introduction}

Nitrogen pollution of the world's oceans is harming marine ecosystem and contributing to global warming. Researches, which involved dozens of scientists from around the world, show that human activity is dramatically altering nitrogen cycles in Earth's oceans, soils and atmosphere. Nitrogen produced by human activity is responsible for nitrous oxide and carbon dioxide input to the world's ocean each year. The accumulation of reactive nitrogen in the environment at alarming rates may be as serious as putting carbon dioxide in the atmosphere [1]. The excess nitrogen can deplete essential oxygen levels in the water and has significant effects on climate, food production, and ecosystems all over the world [2], promote eutrophication and toxicity to aquatic organisms [3] and can cause several problems when discharged into the environment [4] as it is extremely harmful due to the high toxicity of free ammonia at a pH higher than 8 [5]. Because of this tremendous challenge of the global environment, it is, therefore, necessary to remove such substances from wastewater. Further, as environmental and legislative constraints increase, specifically the Philippine Clean Water Act, there is a considerable impetus for reducing the nitrogenous substances for wastewater before its reuse or deposit to the water body. The treatment of wastewater by biological technology has been widely adopted because of its easy operation and low pollution generation [6].

For many years, the traditional method for nitrogen removal from wastewater has been the combination of nitrification-denitrification processes [7]. With the aim to obtain better process stability, some researchers have been focusing on combinations of anaerobic and aerobic processes [8]. Different reactor configurations and sys- 
tems working with one or two reactors can be used [9]. Simultaneous removal of nitrogen and COD can be achieved using the conventional nitrification and denitrification systems. However, over the past few years, new technologies for nitrogen removal have been developed mainly because of the increasing financial costs of traditional wastewater treatment technologies [7]. Some of the novel microbial nitrogen removal processes that have been developed are Single reactor system for High Ammonium Over Nitrite (SHARON) which involves part conversion of ammonium to nitrite, Anaerobic Ammonium Oxidation (ANAMMOX) process which involves anaerobic oxidation of ammonium and the Completely Autotrophic Nitrogen removal Over Nitrite (CANON) process which involves nitrogen removal within one reactor under oxygen-limited conditions [10]. There are other processes that have been developed such as Oxygen Limited Autotrophic Nitrification-Denitrification (OLAND) and a wetland based systems, all with high potential for nitrogen removal.

The development of the above novel microbial nitrogen removal processes is useful in attaining higher efficiency of nitrogen and COD removal from wastewater containing elevated level of nitrogen at a low cost. Prior to the use of these technologies, a preliminary study on the efficiency of nitrogen and organic removal of nutrient-rich simulated wastewater using two different reactors, aerobic and anaerobic, was conducted. This also aims to present the start-up experimentation from these reactors as reference for future study employing any of the above novel nitrogen removal processes.

\section{Materials and Methods}

Experiments were carried out using aerobic and anaerobic reactors. A continuous aerobic reactor was made up of acrylic board with a working volume of 5 liters where an air pump was used for aerobic zone. On the other hand, a continuous anaerobic reactor was made up of a 4-liter Erlenmeyer flask equipped with magnetic stirrer and stir bar to facilitate continuous stirring within the reactor. A photograph of the reactors used in this study is shown in Figure 1. Ports were provided for feeding the sample solution and withdrawing samples for analysis. Two 20-liter buckets were used to collect the effluent from both reactors. The seeding sludge for the laboratory reactors was taken from DLSU- Sequencing Batch Reactor (SBR) wastewater treatment plant.

A simulated wastewater containing glucose as carbon source and ammonium chloride as nitrogen source was prepared as feed to the reactors. It has an approximate COD concentration of $300 \mathrm{ppm}$ and $\mathrm{NH}_{3}-\mathrm{N}$ of $250 \mathrm{ppm}$. This simulated wastewater was continuously fed to aerobic and anaerobic reactors separately. COD test, mixed liquor volatile solid (MLVS), temperature and $\mathrm{pH}$ were performed regularly to monitor the time course until steady state condition was reached.

Batch reactors as shown in Figure 2 were made up of 5 1-liter imhoff cones supported by iron stand and iron ring with different concentrations of wastewater. Air pumps were also used for each reactor for aeration. Wastewater with different concentrations of $\mathrm{NH}_{3}-\mathrm{N}$ and $\mathrm{COD}$ were

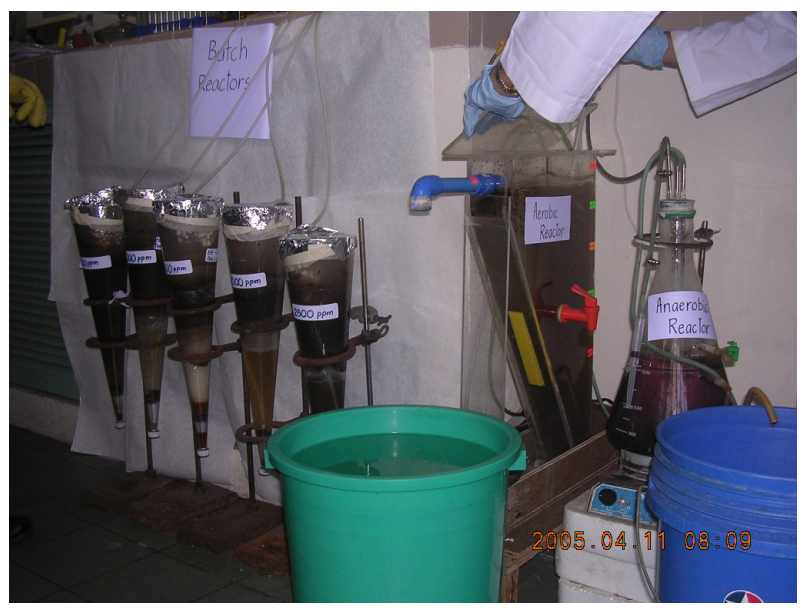

Figure 1. Aerobic and anaerobic reactors.

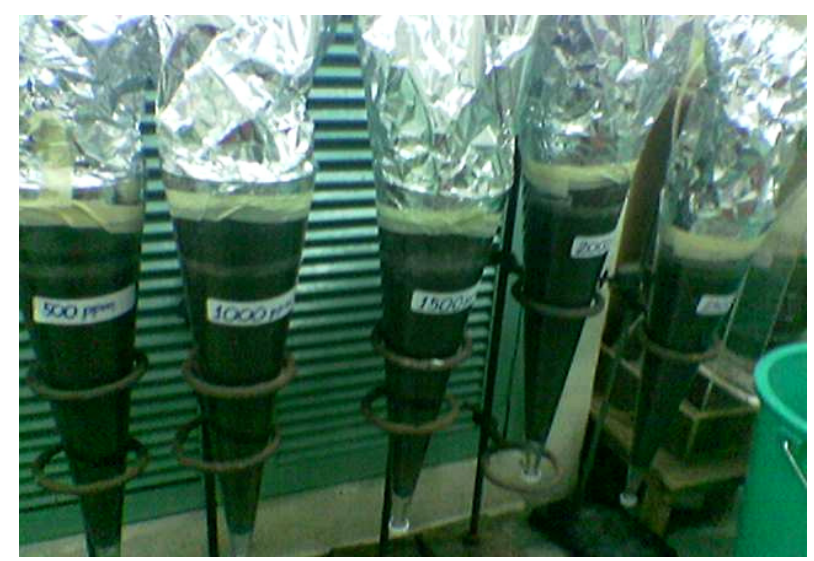

Figure 2. Batch reactors.

Table 1. Initial and final nitrogen concentrations in aerobic batch reactors.

\begin{tabular}{ccccccc}
\hline \multirow{2}{*}{$\begin{array}{c}\text { COD } \\
(\mathbf{p p m})\end{array}$} & \multicolumn{2}{c}{$\begin{array}{c}\text { Ammonia Ni- } \\
\text { trogen }\end{array}$} & \multicolumn{2}{c}{$\begin{array}{c}\text { Nitrite Nitro- } \\
\text { gen }\end{array}$} & \multicolumn{2}{c}{$\begin{array}{c}\text { Nitrate Nitro- } \\
\text { gen }\end{array}$} \\
\cline { 2 - 7 } & $\begin{array}{c}\text { Initial } \\
(\mathrm{ppm})\end{array}$ & $\begin{array}{c}\text { Final } \\
(\mathrm{ppm})\end{array}$ & $\begin{array}{c}\text { Initial } \\
(\mathrm{ppm})\end{array}$ & $\begin{array}{c}\text { Final } \\
(\mathrm{ppm})\end{array}$ & $\begin{array}{c}\text { Initial } \\
(\mathrm{ppm})\end{array}$ & $\begin{array}{c}\text { Final } \\
(\mathrm{ppm})\end{array}$ \\
\hline $\mathbf{5 0 0} \mathbf{~ p p m}$ & 18.89 & 0 & 0 & 9.60 & 0.2707 & 8.7934 \\
$\begin{array}{c}\text { Aerobic } \\
\mathbf{1 0 0 0} \mathbf{~ p p m} \\
\text { Aerobic }\end{array}$ & 30.91 & 0 & 0 & 19.20 & 0.1374 & 8.7542 \\
$\mathbf{1 5 0 0} \mathbf{~ p p m}$ \\
$\begin{array}{c}\text { Aerobic } \\
\mathbf{2 0 0 0} \mathbf{~ p p m}\end{array}$ & 103.13 & 0 & 0 & 93.80 & 0.1726 & 8.7267 \\
$\begin{array}{c}\text { Aerobic } \\
\mathbf{2 5 0 0} \mathbf{~ p p m} \\
\text { Aerobic }\end{array}$ & 137.50 & 0 & 0 & 120.40 & 0.2863 & 8.6954 \\
\hline
\end{tabular}


fed to these reactors to see the effect of various feed concentrations in the removal of nitrogen as shown in Table 1. Furthermore, the same anaerobic reactor was used for batch mode operation. Unless otherwise specified, all parameters in this study were analyzed in accordance with the procedures stipulated in APHA Standard Methods [11].

\section{Results and Discussions}

The COD concentration profile in continuous aerobic reactor was shown in Figure 3 while that of continuous anaerobic reactor was shown in Figure 4. An initial COD of $300 \mathrm{ppm}$ was fed to both reactors until steady state condition was reached. A COD value of $5.47 \mathrm{ppm}$ as shown in Figure 3 was obtained and it became constant after 276 hours or approximately 11 days. Preliminary results showed that $98 \%$ reduction in COD was obtained in aerobic reactor as supported by increasing concentration of MLVS. On the other hand, the COD concentration profile of anaerobic reactor is shown in Figure 4. The same concentration of feed was introduced in the reactor and the COD value of $194.54 \mathrm{ppm}$ was obtained and it became constant after 330 hours, that is approximately at steady state condition after 14 days. Only $34 \%$ reduction of COD was obtained. The above data showed that aerobic bacteria have a higher capability to degrade faster the organic pollutant in wastewater as compared to anaerobic bacteria with the same hydraulic retention time (HRT) of 5 hours in the two reactors.

Figure 5 showed the COD concentration profile of 5 aerobic batch reactors with initial concentrations of 500 , $1000,1500,2000$ and $2500 \mathrm{ppm}$. It was found out that 71 to 97 percent reduction in COD was achieved under aerobic conditions within an average time of 4 to 5 days. The figure also revealed that the higher the COD concentrations, the faster its degradation in its early stage as shown by 2500,2000 and $1500 \mathrm{ppm}$ of COD. On the other hand, 1000 and $500 \mathrm{ppm}$ of COD revealed that it takes a longer time to degrade. High COD loading resulted in a low COD removal of $71 \%$. The absence of trend in these results maybe attributed to the various MLVS concentrations in the reactors since the carbon to nitrogen $(\mathrm{C} / \mathrm{N})$ ratio in all reactors were almost the same.

Initially, ammonia concentrations of the aerobic batch reactors were $18.89,30.91,103.13,137.50$ and 171.86 ppm. Wastewater sample had no nitrite-nitrogen but nitrate was present in a small amount as shown in Table 1. It was very evident that ammonia has been totally degraded at the end of 5 days to nitrite and nitrate with the help of ammonium oxidizing bacteria (AOB) that live in an aerobic environment. However, it was also observed that the higher the concentration, the longer it takes to degrade ammonia.

Figures 6 and 7 showed the nitrogen concentration

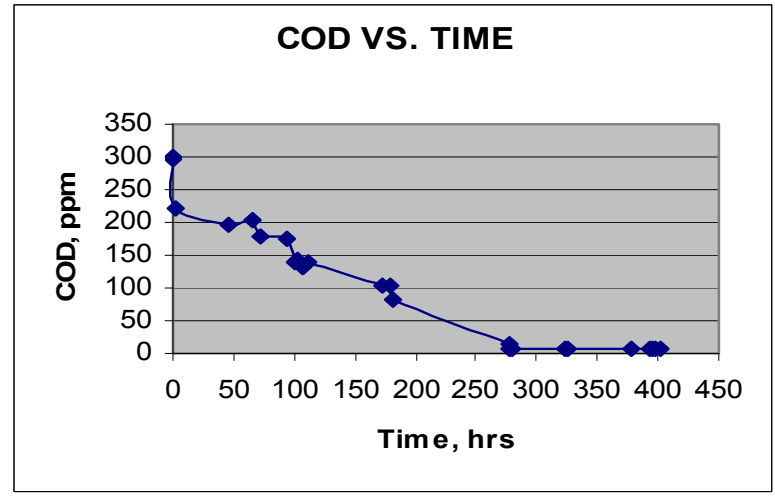

Figure 3. COD vs. Time.

(Continuous aerobic)

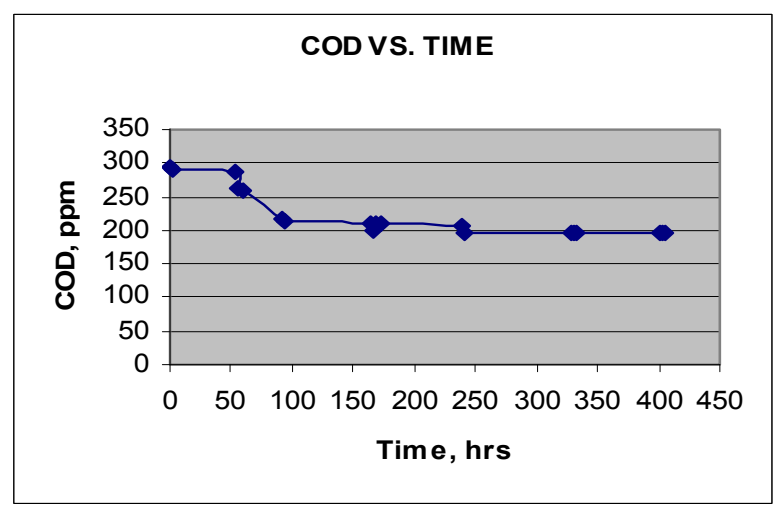

Figure 4. COD vs. Time.

(Continuous anaerobic)

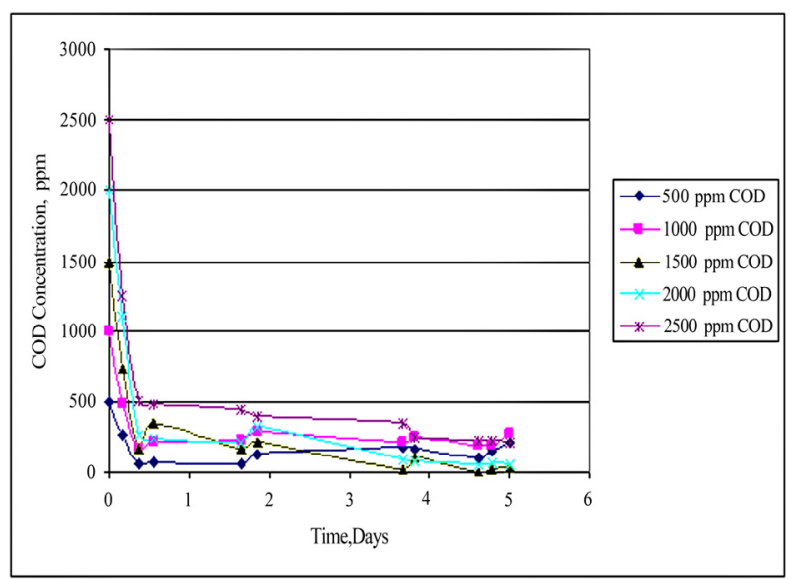

Figure 5. COD concentration profile in aerobic batch reactors.

profile in aerobic batch reactors. The lowest concentration used for $\mathrm{NH}_{3}-\mathrm{N}$ was 18.89 ppm as shown in Figure 6 and the highest concentration used for $\mathrm{NH}_{3}-\mathrm{N}$ was $171.86 \mathrm{ppm}$ as shown in Figure 7. It was very evident from Figure 6 that the 18.89 ppm $\mathrm{NH}_{3}-\mathrm{N}$ be- 


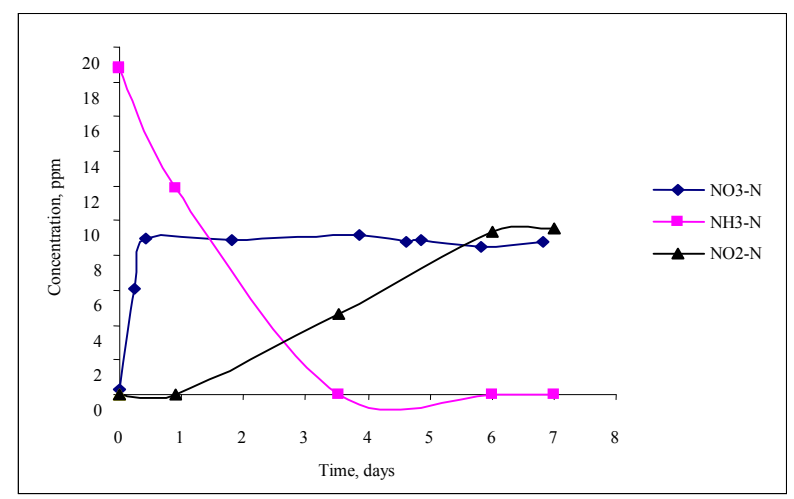

Figure 6. Nitrogen concentration profile in aerobic batch reactor $(500 \mathrm{ppm}$ of $\mathrm{COD})$.

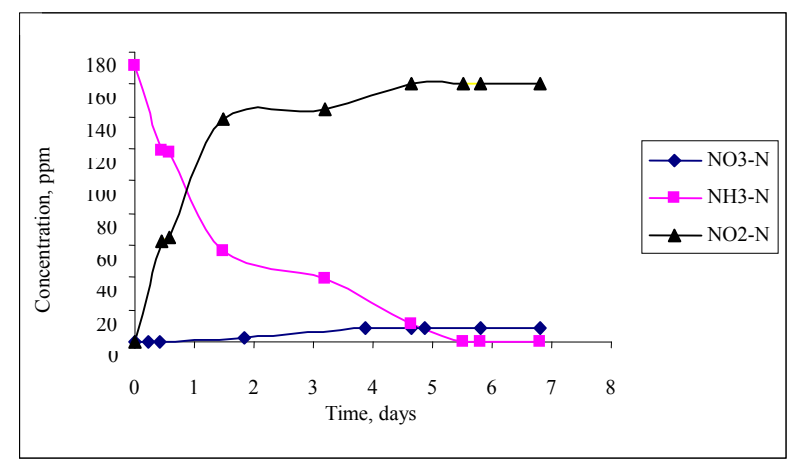

Figure 7. Nitrogen concentration profile in aerobic batch reactor $(2500 \mathrm{ppm}$ of $\mathrm{COD})$.

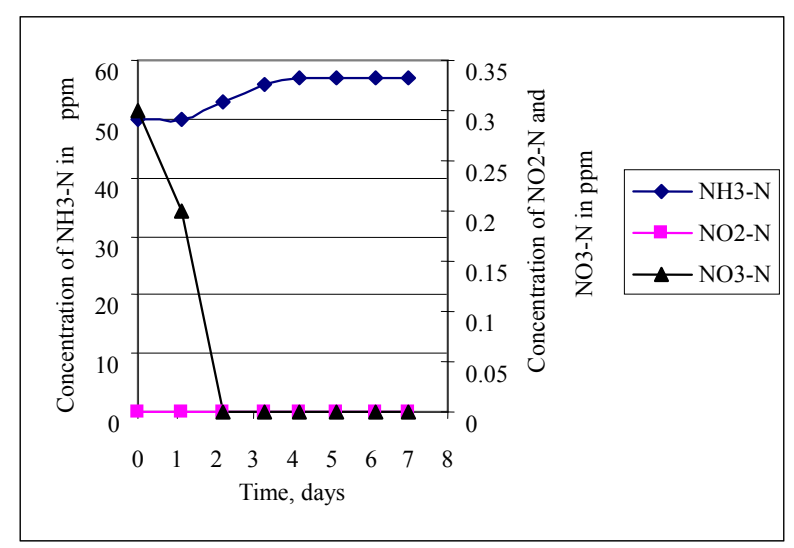

Figure 8. Nitrogen concentration profile in anaerobic batch reactor.

came totally degraded after 3.5 days while $171.86 \mathrm{ppm}$ $\mathrm{NH}_{3}-\mathrm{N}$ was totally degraded after 5.5 days. This revealed that the time to degrade $\mathrm{NH}_{3}-\mathrm{N}$ also depends on the concentration of the feed, that is, the higher the concentration of $\mathrm{NH}_{3}-\mathrm{N}$, the longer the time required for its degradation assuming the same condition and biomass concentration in the reactor. It was also found out that the concentrations of $\mathrm{NO}_{2}-\mathrm{N}$ and $\mathrm{NO}_{3}-\mathrm{N}$ increased in both reactors. These results could be attributed to the activity of ammonium oxidizing bacteria (AOB) converting $\mathrm{NH}_{3}-\mathrm{N}$ to $\mathrm{NO}_{2}-\mathrm{N}$ and $\mathrm{NO}_{3}-\mathrm{N}$ in aerobic environment. On the other hand, $\mathrm{NO}_{2}-\mathrm{N}$ also increased in both reactors while there was a slight increase in $\mathrm{NO}_{3}-\mathrm{N}$ concentration. It was suspected that the concentration of dissolved oxygen in the reactor was limited for further oxidation of nitrite to nitrate due to the higher affinity to oxygen of the ammonia than the nitrite oxidizing bacteria (NOB). One possible reason is maybe due to uncontrolled $\mathrm{pH}$ in the reactor resulting in partial nitrification. Presence of inhibitors for nitrite oxidizing bacteria may also be possible for low conversion of nitrite to nitrate though the microorganisms can adapt to the inhibitor after a long period of application and decrease its inhibiting efficiency [12].

Figure 8 showed the nitrogen concentration profiles of $50 \mathrm{ppm} \mathrm{NH}_{3}-\mathrm{N}$ and $1000 \mathrm{ppm}$ of COD in an anaerobic batch reactor. Theoretically, no ammonia conversion was expected in an anaerobic environment, only nitrate or nitrite conversions. Autotrophic nitrifiers need oxygen to be able to convert ammonia to nitrite and then to nitrate. However, from the result of the experiments, ammonia concentration was observed to have increased slightly. This may be attributed to the formation of ammonia from the protein content of wastewater dissociated in water. Based on the previous study, the effluent ammonia concentration sometimes exceeded the corresponding influent ammonia concentration due to ammonification of organic nitrogenous compounds under anaerobic conditions [13]. This may also be due to some organic compounds that have been found to be degraded to simple organic acids, alcohol, etc., rather than $\mathrm{CO}_{2}$ and $\mathrm{H}_{2} \mathrm{O}$ under anaerobic conditions which also limited COD reduction in the same condition [14]. Initially, there was no nitrite in the reactor and remained constant throughout. On the other hand, $0.3 \mathrm{ppm}$ nitrate nitrogen was totally degraded under anaerobic condition due to denitrification process where nitrate was reduced to nitrogen gas. COD reduction in anaerobic environment maybe attributed to synthesis of biomass and methane gas $[15,16]$.

The time course of biomass growth was monitored by measuring the biomass concentration represented by mixed liquor volatile solids (MLVS). The increasing concentration of MLVS suggested that the removal of nitrogen and COD in the two reactors is possible.

\section{Conclusions}

From the experimental results obtained, the following conclusions can be drawn:

1) At the same HRT, 98\% reduction in COD was obtained in aerobic reactor against $34 \%$ reduction in anaerobic reactor, therefore, anaerobic bacteria have a slower capability to degrade organics.

2) Nitrite accumulation and low nitrate build up in aerobic reactor was observed because of the low activity 
of NOB maybe due to the presence of inhibitors or uncontrolled $\mathrm{pH}$ in the reactor during nitrification.

3) Aerobic process requires longer aeration time and produces large amount of sludge but they can remove ammonium nitrogen.

4) Anaerobic treatment methods usually offer advantages such as higher organic loading rates and production of usable biogas, however a relatively higher effluent concentration and incapability to remove ammonium nitrogen are some of its disadvantages.

5) Therefore, based on the above findings, it is more attractive to use combined anaerobic and aerobic systems for simultaneous removal of nitrogen and COD.

\section{Acknowledgments}

The authors wish to thank the Department of Science and Technology- Philippine Council for Industry and Energy Research and Development (DOST-PCIERD) and CHED Center for Excellence in Chemical Engineering for the financial support for this research project, De La Salle University-Manila and Technological Institute of the Philippines-Manila. Special thanks to Mr.Lucky Uy, Mr. Jorich Gaw and Ms. Diane Dy.

\section{References}

[1] J. N. Galloway, "Transformation of the nitrogen cycle: Recent trends, questions and potential solutions," Science Journal, May 2008.

[2] R. A. Duce, "Impacts of atmospheric anthropogenic nitrogen on the open ocean," Science Journal, May 2008.

[3] F. Moharram and R. Bhargava, "The Optimum stage for nitrification efficiency in the biofilm-ASP reactor," ICWNR'04, pp 24-31, 2003.

[4] M. Kermani, B. J. Bina, H. Movahedian, M. M. Amin, and M. Nikaeen, "Biological phosphorous and nitrogen removal from wastewater using moving bed biofilm process," Iranian Journal of Biotechnology, Vol. 7, No. 1, 2009.

[5] V. Reginatto, R. M. Teixeira, F. Pereira, W. Schmidell, J. A. Furigo, R. Menes, C. Etchebehere, and H. M. Soares, "Anaerobic ammonium oxidation in a bioreactor treating slaughterhouse wastewater," Brazilian Journal of Chemical Engineering, Vol. 22, No. 4, 2005.
[6] X. Zheng, J. Tong, H. J. Li, and Y. G. Chen, "The investigation of effect of organic carbon sources addition in anaerobic-aerobic (low dissolved oxygen) sequencing batch reactor for nutrients removal from wastewaters," Bioresource Technology, Vol. 100, pp. 2515-2520, 2009.

[7] D. Paredes, P. Kuschk, T. S. A. Mbwette, F. Stange, R. A. Muller, and H. Koser, "New aspects of microbial nitrogen transformations in the context of wastewater treatment: A review," Engineering Life Science, Vol. 7, No. 1, pp. 13-25, 2007.

[8] S. W. Hu, F. L. Yang, S. T Liu, and L. G. Yu, "The development of a novel hybrid aerating membrane-anaerobic baffled reactor for the simultaneous nitrogen and organic carbon removal from wastewater," Water Research, Vol. 43, pp. 381-388, 2009.

[9] C. P. L Grady, G. Daigger, and H. Lim, "Biological wastewater treatment," $2^{\text {nd }}$ Edition, Revised and Expanded, Marcel Dekker Inc., N.Y., 1999.

[10] T. Khin and A. P. Annachhatre, "Novel microbial nitrogen processes," Biotechnology Advances, Vol. 22, No. 7, pp. 519-532, 2004.

[11] APHA/AWWA/WEF, "Standard methods for the examination of water and wastewater," $18^{\text {th }} \mathrm{Ed}$., Washinton DC, USA., 1992.

[12] A. M. Corral, F. Gonzalez, J. L. Campos, and R. Mendez, "Partial nitrification in sharon reactor in the presence of salts and organic carbon compounds," Process Biochemistry, Vol. 40, pp. 3109-3118, 2005.

[13] R. He, X. W. Liu, Z. J. Zhang, and D. S. Shen, "Characteristics of the bioreactor landfill system using an anaerobic-aerobic process for nitrogen removal," Bioresource Technology, Vol. 98, pp. 2526-2532, 2007.

[14] W. Li and S. K. Zheng, "A combination of anaerobic and aerobic treatment for ammonia-laden coke plant effluent: The pilot study," International Society for Environmental Information Sciences, Vol. 2, pp. 602-610, 2004.

[15] S. Chen, D. Z. Sun, and J. S. Chung, "Simultanoeous removal of COD and ammonium from landfill leachate using an anaerobic-aerobic moving bed biofilm reactor system," Waste Management, Vol. 28, pp. 339-346, 2008.

[16] J. H. Im, H. J. Woo, M. W. Choi, K. B. Han, and C. W. Kim, "Simultaneous organic and nitrogen removal from municipal landfill leachate using an anaerobic-aerobic system," Water Research, Vol. 35, pp. 2403-2410, 2001. 